\title{
From Revolution to Resolution: Exploring Third-Party Mediation in Nonviolent UPRISINGS
}

\section{by Isak Svensson and Magnus Lundgren}

Nonviolent protest movements have been prevalent in the last decades. While such movements aim for peaceful change, they are frequently followed by civil war. Previous research has shown that outcomes of nonviolent protests can be influenced by mediation, but because most previous research on conflict mediation has predominately examined armed conflicts, little is known about when and how mediation occurs. We argue that mediation in nonviolent uprisings is more likely when social conflicts generate negative externalities for the outside world, incentivizing third parties to act and conflict parties to accept their terms. After assessing the scope of the empirical field and identifying anchoring points for future research, we examine data on nonviolent campaigns between 1970 and 2014 , investigating patterns in mediation incidence across time and space by situational characteristics, and by the origins of the mediator. We find that protest movements with a higher risk of violent escalation, marked by radicalism or state repression, are more likely to be mediated, and that mediation of nonviolent disputes has shifted from domestic to international mediators. We conclude by discussing theoretical implications for the field as well as suggesting some important policy and practice implications for the mediation of nonviolent conflicts.

\section{INTRODUCTION}

Full-scale civil wars are sometimes preceded by nonviolent uprisings. Recent examples include the nonviolent uprisings in Syria 2011, whose failure ushered in civil war, and in Ukraine in 2013, whose success also brought civil war in the form of repressive countermeasures. Mediation efforts were largely lacking during the nonviolent phase of

PEACE \& CHANGE, Vol. 43, No. 3, July 2018

(C) 2018 Peace History Society and Wiley Periodicals, Inc. 
the Syrian conflict, and the mediation efforts in Ukraine failed to prevent further escalation of the conflict. Thus, in order to understand the possibilities and obstacles for conflict resolution in civil wars, scholars and practitioners need a better understanding of the dynamics of nonviolent conflicts and particularly the role of third-party mediation in that context.

Previous research on conflict mediation has predominately examined armed conflicts. Mediation research has traditionally focused on interstate armed conflicts and militarized disputes ${ }^{1}$ and has only in the last decade examined mediation in conflicts that have taken place within states rather than between them. ${ }^{2}$ Yet not all such conflicts involve armed violence: an opposition group challenging the status quo can utilize directed civil action against a regime without necessarily resorting to arms, relying instead on public protests, boycotts, civil disobedience, strikes, and other nonviolent strategies to demand or compel change. ${ }^{3}$ Thus, research on mediation and other forms of third-party engagement is mostly concentrated on armed conflicts, yet mediation has clearly been influential within nonviolent uprisings. Exceptions to this general trajectory exist and include work on mediation in ethnic conflicts, ${ }^{4}$ and UN mediation and other forms of conflict management efforts in the context of self-determination disputes within countries. ${ }^{5}$ Yet, so far, no studies have systematically examined the broader set of nonviolent uprisings and the variations in terms of which of these that are mediated, and which that are not. ${ }^{6}$

Nonviolent protest movements have been prevalent around the world, and their outcomes have shaped the trajectory of democratic governance in several countries. ${ }^{7}$ The data show that nonviolent campaigns have been more effective in bringing about aspired change, such as democratization of authoritarian rule, compared to armed campaigns. ${ }^{8}$ Nonviolent opposition movements in Burkina Faso in 2014, Serbia in 2000, and the Philippines in 1986 are three examples from different decades and different regions that exemplify the potential for active nonviolent opposition in bringing about regime change. The study of strategic civil resistance has shown that the outcome and dynamic of nonviolent conflicts can be explained by, among other factors, the ability to generate large-scale and society-wide participation, ${ }^{9}$ the extent to which government repression backfires, ${ }^{10}$ and the possibility of creating loyalty shifts among key actors, such as security forces. ${ }^{11}$ Mediation, however, may form another significant factor 
which, as of yet, has not been studied as extensively as the three above.

While there are relatively few works of scholarship on the mediation on nonviolent uprising, anecdotal evidence points to its pivotal role in shifting political dynamics at critical junctures. Cases, such as Ukraine in 2013, Yemen in 2011, Israel-Palestine in the 1990s, and Tunisia in 2011, are illustrative in this regard. There have been cases of popular-based nonviolent uprisings for regime change or for state formation (through secession/end of occupation), but there have also been cases of mediated interventions by the European Union in Ukraine, the Gulf Cooperation Council (GCC) in Yemen, by Norway and later United States in the Israel-Palestine dispute, and by the "Quartet" in Tunisia. These mediation efforts show mixed results: the internally driven mediation process in Tunisia has shown to be the most durable; in the cases of Israel-Palestine and Yemen, mediation led to agreements that eventually broke down in armed conflicts, and in the case of Ukraine, no comprehensive agreement was reached. What these four cases show is that mediation was an important part of the dynamics of how these conflicts developed. Thus, they point to the need for a greater understanding of why mediation occurs in nonviolent uprisings.

The omission of mediation in the context of nonviolent uprisings within the scholarly literature reflects larger configurations of the earlier subfields within conflict studies. The fields of conflict resolution or conflict management, on the one hand, and the field of strategic nonviolence, on the other, have been two research fields working in silos. In examining the role of mediation in nonviolent conflicts, this study offers a means of merging insights from these two fields. It also remedies the underutilization of conflict resolution practices in the context of nonviolent uprisings that has resulted from an overemphasis on separating "theory" from "practice." An important rationale for this study, and in keeping with the theme of this special issue, lies in its policy relevance. Research on the use of mediation in nonviolent uprisings provides a broader picture of the policy repertoire available to the international community, models for conflict prevention, and contributions toward an evidence-based practice of mediation in nonviolent uprisings.

This study sets out to examine the question: Under what conditions does third-party mediation occur in nonviolent uprisings? Our aim is to start the process of scoping the field of mediation in 
nonviolent uprisings and to chart theoretical anchoring points for future academic research. This mapping of the domain of mediation in nonviolent uprisings will form a foundation on which research on nonviolence and on conflict resolution can start to be more fruitfully integrated. Within this terrain is our own central finding from our study of nonviolent uprisings from 1970 to 2016, drawn from the Nonviolent and Violent Campaigns and Outcomes (NAVCO) Data Project, which is a data collection effort of major nonviolent and violent resistance campaigns worldwide. It explores the conditions under which mediation attempts occur, utilizing updated data on mediation originally presented in an earlier study. ${ }^{12}$ Our results suggest that mediation in nonviolent uprisings is driven to a large extent by the campaigns' risk potential and expected costs. One or more conflict parties are more likely to request and receive mediation when the regime, opposition, and third parties have incentives. This suggests, therefore, that high-risk and high-cost situations are more amenable to the influence of third-party engagement.

\section{THEORY}

"Mediation" is a term utilized to describe the involvement of an intermediary in an antagonistic relationship between at least two groups that have incompatible claims and engage in behaviors that challenge the other sides' power base. A mediator is an actor-an individual, organization, country or group of countries-who helps the parties in conflict to achieve some degree of conflict resolution (an agreement settling all or part of the central dispute) or conflict management, which involves decreasing the use of violence between the conflict parties. A third-party mediator may be related due to previous ties to the primary parties in conflict (such as a biased mediator). Mediators utilize a wide range of techniques that may include transmitting information between the parties, arranging meetings, proposing solutions, building relationships, offering side-payments to the primary parties in exchange for concessions, threatening to take costly action against reluctant parties, offering to guarantee agreements, and many others, depending on the particular dynamics of the conflict, the preferences of the mediator, and the type of mediation required. ${ }^{13}$

Mediation is a process of conflict management and resolution, which falls in a realm between two other forms of interventions: force and international law. ${ }^{14}$ It is distinguishable from legal approaches, 
such as international arbitration, in the sense that it relies primarily upon the power of persuasion and bargaining, rather than on the implementation of international law. Whereas the outcome of arbitration is ultimately in the hands of judges, the outcome of mediation is something that must be agreed upon by the disputants. Intervention by force, such as military intervention, is not necessarily undertaken with the acceptance of all conflict parties, and is in fact often conducted in direct opposition to one of the sides in conflict. Therefore, mediation can be performed by a party with the leverage that comes with having previously intervened by force, or who can credibly threaten to do so in the future. Yet most definitions of mediation convey an implicit assumption of exclusively peaceful intervention, in which the third party would never refer to or resort to the use of armed force.

This means that mediation is ultimately an intervention that rests on the acceptance of the parties in conflict. It requires a three-way negotiation process through which the terms of mediation are agreed: all sides in a conflict as well as the potential third-party mediator need to accept the role of mediation in order for it to occur. It is important to note that mediation attempts through belligerents' requests or third parties' offers are not always accepted. ${ }^{15}$ It is also important to recognize that mediation may occur for reasons other than the readiness of one side to earnestly seek a negotiated way out of its situation. The parties may, for instance, engage in conflict mediation to achieve such objectives as buying time to regroup and rearm, to enhance their relationship with the third party, or to win international recognition and enhance their public image. ${ }^{16}$ Similarly, mediators may engage in order to achieve other objectives, such as gaining influence, building their reputation, or safeguarding various national interests. ${ }^{17}$

An important insight into the study of mediation is that it tends to occur at the point at which the conflict parties have escalated their conflict to the point where further escalation has become too costly in a political, economic, material, or other sense. In stalemated situations, the mediator can be one of the few actors to reconfigure the relationships between the hostile parties, so when the cost of the stalemate reaches an intolerable threshold, one or more of the conflict parties have the incentive to engage in the mediation process. Thus, stalemates are usually a precondition for the conflict parties' re-evaluation of their reliance on unilateral strategies, and their openness to collaborative approaches to settling the conflict. The intensity of a conflict also helps to explain why mediation occurs, because it 
incentivizes belligerent actors to seek alternatives to the battlefield. ${ }^{18}$ By the same logic, in addition to conflict intensity, conflict duration can help to account for the likelihood of mediation to occur. ${ }^{19}$ Conflict parties can also be more inclined to resort to mediation when the conflicts become increasingly complex and, by extension, intractable. ${ }^{20}$

Parties in conflict may have different incentives for engaging in mediation. In general, regimes and leaders of governments may be reluctant to engage in mediation out of concern for the appearance that the government has lost control of civil order and that the opposition cause could gain legitimacy. Rhetorically, regimes tend to dismiss opposition movements that have taken to the streets as "terrorists," "provocateurs," "foreign agents," and the like. When regimes admit their need for international mediators to facilitate a settlement with the groups that they previously cast as a weak political fringe, it comes at a cost to their image, which may in turn bear on their future capacity to govern. ${ }^{21}$ Thus, governments have incentives to engage in bilateral direct negotiation rather than involving a third party. Unless the situation is becoming unruly, and the relationships are deteriorating beyond repair, governments will, in most cases, resist mediation attempts to the greatest extent possible. In contrast, when the situation threatens a political cost that the government knows it cannot recoup, the incentive to settle the conflict through mediation will increase.

Opposition groups also have different incentives to engage in mediation. Mediation is a form of conflict resolution and management that brings de-escalatory dynamics to conflict. It builds ultimately on a controlled group polarization. ${ }^{22}$ Activists challenging a regime may escalate their conflict (through nonviolent means) and may be reluctant to engage in talks with the challenged regime as such talks may serve to decrease the sense of revolutionary momentum in an uprising. From the perspective of the opposition, the sequence of revolution and resolution is essential. ${ }^{23}$ The fundamental power imbalance between the status quo power of the regime and the challengers needs to be addressed before any meaningful negotiation can take place, lest the negotiation achieve nothing more than the stronger imposing its will upon its weaker opponent. ${ }^{24}$ Thus, mediation needs to occur when the nonviolent opposition has been sufficiently successful in challenging the regime's hold on power such that it is in the regime's interest to listen, negotiate, and make substantial changes to its earlier position. Mediation entails a risk of pacification leading to preemptively ending the conflicts before fundamental power shifts have occurred. ${ }^{25}$ Still, 
the opposition may turn to mediation if the conflict is at risk of escalating to violence and civil war, which it may deem too costly to pursue.

Mediators, like the conflict parties themselves, have incentives to offer their services and to commit resources to settle a conflict when a nonviolent conflict threatens to create negative externalities, including the risks of escalation to civil war and of wider instability and chaos. Their roles are politically sensitive in ways that are analogous to the hostile parties. As an example, mediators face trade-offs between entering early to preempt escalation with lower levels of procedural control and bargaining power, or waiting until the conflict escalates so that while the problem is more severe, the mediator has more bargaining power because the parties' alternative to mediation has grown worse. $^{26}$

The occurrence of mediation is thus driven by the complex interplay of both capabilities and incentives for interventions of all parties to engage in conflict and negotiate toward a potential settlement. Mediators may either have interests in a particular conflict (or the way it should get resolved), and/or, as in the case of the UN or the Red Cross, have a general interest in pursuing peaceful solutions to armed conflicts. ${ }^{27}$ The analysis of the basis upon which mediators, governments, and opposition engage in mediation processes to end conflict point to a general trajectory: the occurrence of mediation in unarmed uprising may be expected to be driven by the risk of escalation and a worsening situation. Factors associated with greater costs and higher risks of violence should also, we expect, be associated with a greater likelihood of mediation.

\section{MAPPING MEDIATION IN NONVIOLENT UPRISINGS}

As a scoping study aimed at mapping the empirical domain of mediation in nonviolent uprisings as an emerging field of inquiry, we do not set out to provide a comprehensive model explaining the occurrence of mediation. Rather, our more limited aspiration is to provide some initial empirical analysis that can hopefully inspire further research analyzing the conditions that explain both mediation occurrence and the conditions under which mediation may be successful. Our approach is descriptive rather than explanatory; instead of subjecting causal propositions to systematic tests, we examine, via 
descriptive statistics, crosstabs, and graphical comparisons, how mediation in nonviolent uprisings varies with factors of theoretical interest.

To map mediation occurrence, we combine historical data on nonviolent protest movements from the Nonviolent and Violent Conflict Outcomes (NAVCO) 2.0 data set $^{28}$ with updated data on mediation originally presented in our previous research in $2013 .{ }^{29}$ We draw from the NAVCO data to include observations on nonstate resistance campaigns between 1979 and 2006. Katariina Mustasilta and Isak Svensson, relying on NAVCO coding criteria, extended the data to cover the 2007-2014 period. ${ }^{30}$ We rely on the combined data set, covering nonviolent campaigns between 1970 and 2014. A campaign is defined as continuous, purposive mass tactics, or events in pursuit of a political objective, such as expelling foreign occupiers, ousting dictatorships or military juntas, improving self-determination, or other types of social change (e.g., changing the system of apartheid in South Africa). ${ }^{31}$ Campaigns are considered nonviolent if they are "prosecuted by unarmed civilians who did not directly threaten or harm the physical well-being of their opponent."32

We code each campaign as mediated or not, using data from Factiva, the Global Nonviolent Action Database, and secondary sources. ${ }^{33}$ A nonviolent campaign is considered as mediated if at least one side intervened in the conflict with the consent of the parties (opposition and government) in an attempt to facilitate a solution, or at least to get the parties to communicate with each other. Our conceptualization of mediation is in line with previous mediation research: mediation is a voluntary process in which a third-party actor assists the disputing parties without utilizing force, and without employing the legal processes of arbitration and international law. We conceptualize mediation in its broadest form to include the supply of good offices, direct negotiation, shuttle diplomacy, facilitation, bargaining, and face-toface dialogue.

We start by examining the empirical trends over time in terms of the occurrence of mediation in nonviolent uprisings. In Figure 1, the number of nonviolent uprisings is illustrated, together with the proportion of uprisings receiving mediation. We first observe that there is significant variation in the incidence of nonviolent campaigns over time. It was low in the 1970 s, but grew in the 1980 s to a peak immediately before and after the end of the Cold War, when the yearly average was more than a dozen cases, with some years totaling more than twenty cases. The incidence of nonviolent campaigns then 


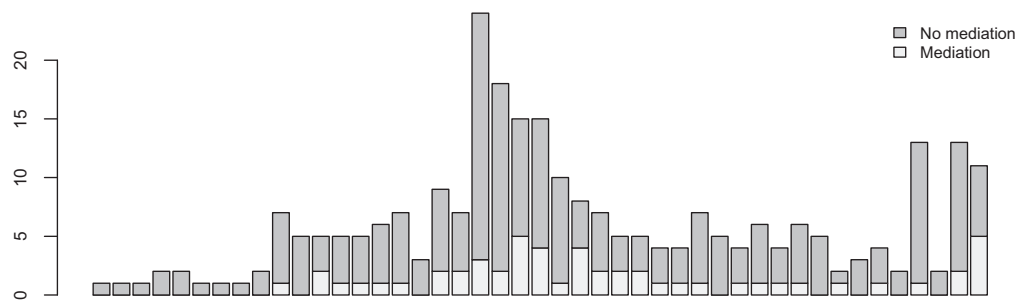

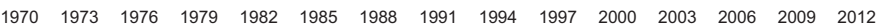

Figure 1. Mediated and nonmediated nonviolent campaigns, 19702014.

decreased, returning to the level of the 1980s and holding steady until the 2010s, when there were several years with more than a dozen annual observations. Thus, two periods, 1989-1993 and 2011-2014, exhibit a higher than average incidence of nonviolent uprisings, reflecting the popular revolutions that characterized the end of the Cold War and the "Arab Spring," respectively. In such years of intense political turmoil, we observe an average annual campaign count that is significantly above the average of 4.2 campaigns for years outside of these two periods. We also observe that the incidence of mediation of nonviolent campaigns follows a similar pattern, peaking in the late 1980s and early 1990s, with a suggested increase in 2014, the last year in our data. This pattern mirrors that of the incidence uprisings, suggesting that the rate of mediation has remained relatively stable across time. Importantly, in any given year, a minority of the uprisings are mediated, and the overall rate of mediation is 19 percent.

The above data suggest that mediation of nonviolent campaigns is relatively rare, potentially because disputants frequently view the aforementioned risks, including loss of face or strategic momentum, as prohibitive. Alternatively, these numbers may be explained by the fact that many nonviolent campaigns do not generate sufficiently high risks to incentivize mediation. At the same time, we see that mediation does indeed occur in many places. In the following, we examine variation across factors relating to geography, characteristics of the uprising, and the origins of the mediator.

Turning to geographical variation, Figure 2 describes the geographical distribution of uprisings together with information on the proportion that received mediation. The incidence of nonviolent campaigns and the rate of mediation appear to be relatively similar across 


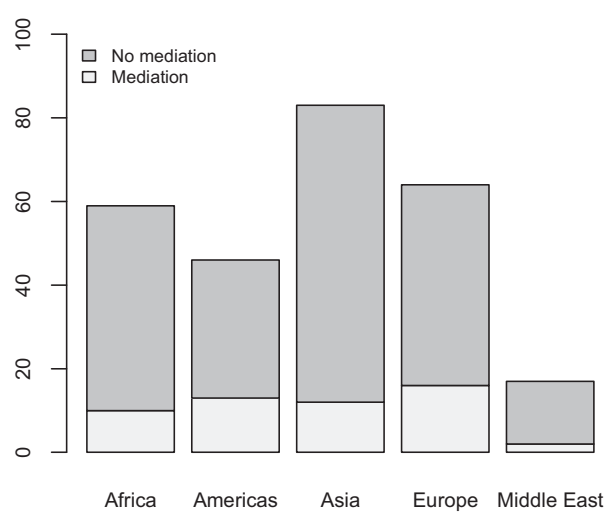

Figure 2. Mediated and nonmediated nonviolent campaigns by region.

regions, with the exception of the Middle East. In the Middle East, there have been fewer nonviolent uprisings, and of the seventeen that are recorded since 1970, only two have received mediation. ${ }^{34}$ This means that an uprising in the Middle East has been about half (11.7 percent) as likely to receive mediation as uprisings taking place elsewhere in the world (20.2 percent).

Let us continue to examine some of the characteristics associated with mediated nonviolent uprisings. Above, we suggested that nonviolent uprisings at risk of violent escalation (to civil war or societal breakdown) should be more likely to receive meditation. One indicator of this could be the presence of radicalized actors, as such actors characterized by more extreme demands and methods relative to other protest groups. ${ }^{35}$ Previous research suggests that the existence of radical flanks is an important element affecting the dynamics of nonviolent uprisings. ${ }^{36}$ While such tactics can increase the leverage of a campaign, they also increase the likelihood of a government crackdown, raising the probability of violent escalation. ${ }^{37}$

\section{Radical Flanks}

In Figure 3 and Table 1, we compare the mediation incidence across campaigns with and without radical flanks. We observe that the majority of nonviolent campaigns recorded in our data do not have radical flanks but, more importantly, that the third that does have such flanks is more likely to attract mediation. Only 14 percent 


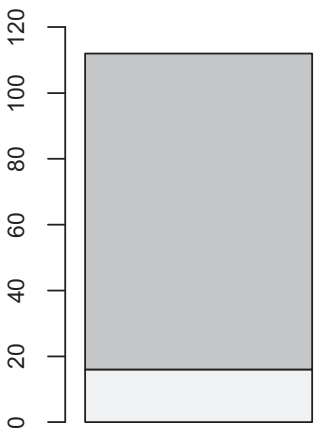

No radical flanks

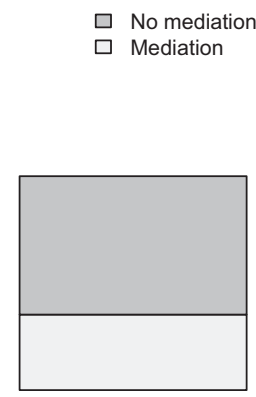

Radical flank(s)

Figure 3. Mediated and nonmediated nonviolent campaigns by the presence of radical flanks.

Table 1 Mediation Incidence in Nonviolent Campaigns with and without Radical Flanks

\begin{tabular}{lccc}
\hline & No Mediation & Mediation & Total \\
\hline No radical flanks & $96(86 \%)$ & $16(14 \%)$ & 112 \\
Radical flank(s) & $42(65 \%)$ & $23(35 \%)$ & 65 \\
Total & 138 & 39 & 177 \\
\hline
\end{tabular}

Note: Percentages refer to the percent that gets mediated or not within category. Pearson's $\chi^{2}=9.47, d f=1, p$-value $=0.002$.

of campaigns without radical flanks receive mediation, compared with 35 percent of campaigns where they are present. Examples include the 1987 protests against the military regime in South Korea, the mid-1980s anti-Pinochet movement in Chile, and the so-called Tulip Revolution in Kyrgyzstan in 2005. A possible interpretation is that campaigns that contain radicals, or that become radicalized, generate greater risks of negative externalities, incentivizing mediation. This interpretation is supported by the additional observation that radicalized campaigns are more likely to attract international mediators, whereas nonradicalized campaigns are more likely to attract domestic mediators.

\section{State Repression}

We turn next to the factor that is frequently cited as a motivation for radicalization of social movements, namely, state repression. As is 
observed in Figure 4, the majority (85 percent) of nonviolent uprisings were met with governmental repression. This means that the political center sought to actively suppress, with violence or other means, the challenge directed against it. In half of the observed cases, repression was categorized as "extreme," suggesting that the typical regime response to a nonviolent uprising is suppression involving violent means. One example recorded in our data is the Tibetan revolt of 1987-1989. This protest movement, which sought the expansion of political and social freedoms in Tibet, was contemporary with other public protests in China, most famously the events in the Tiananmen Square in Beijing, and was similarly met with a military crackdown.

The Tibetan revolt, perhaps owing to the noninterventionist leanings of the Chinese government, did not experience any mediation attempt. However, as Figure 4 (and Table 2) demonstrates, nonviolent uprisings that are met with intense repression are otherwise more

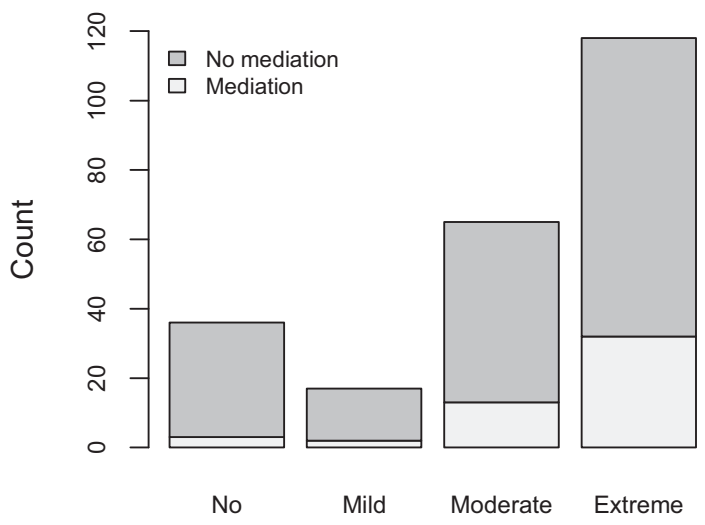

Repression

Figure 4. Mediated and nonmediated nonviolent campaigns by degree of repression.

Note: Repression is coded based on NAVCO 2.0 data in Chenoweth and Lewis ("Unpacking Nonviolent Campaigns: Introducing the Navco 2.0 Dataset," Journal of Peace Research 50, no. 3 (2013): 415423), based on their qualitative coding of the degree of state repression in response to campaign activity. The variable ranges from "no" repression to "extreme" repression, depending on the scope and intensity of violence used by the state. See NAVCO 2.0 codebook. 
likely to see mediation than uprisings with no or less intense levels of repression. Of the 118 cases in which protests involved "extreme" repression, thirty-two (or 27 percent) involved some kind of mediation, compared with only 8 percent in the cases without repression. These patterns are congruent with our theoretical expectation that factors that increase the risk of escalation and widespread harm are more likely to trigger a search for mediation initiatives. Our data do not allow us to identify the exact origins of mediation initiatives launched in response to escalation, but several of them are initiated by outside actors, such as intergovernmental organizations.

An example from our data that seems to fit this pattern is Yemen in 2011. In Yemen, fears that "the regime's violent suppression of protests could have turned immediately into open war" motivated the UN to rapidly appoint an envoy, Jamal Benomar, to mediate the accelerating dispute. ${ }^{38}$ Another example is Syria, where an uprising contemporaneous with that in Yemen attracted several attempts at mediation. In Syria, early mediation interventions by both the Arab League and the UN were strongly motivated by fears that regime repression risked feeding into a process of escalating violence. ${ }^{39}$ While these mediation attempts ultimately could not prevent either country from descending into civil war, they clearly illustrate that mediation of nonviolent campaigns may be motivated by the fear that they will do so.

\section{Domestic and International Mediators}

Who are the mediators? There are many ways in which mediators can be categorized, and a wider analysis of which type of mediators that engage with nonviolent uprisings falls beyond the scope of this study. Yet we recognize that a widening discussion has started to examine the role of mediators from the inside, labeling them "insider

Table 2 Mediation Incidence in Nonviolent Campaigns by Degree of Repression

\begin{tabular}{lccr}
\hline & No Mediation & Mediation & Total \\
\hline No repression & $33(92 \%)$ & $3(8 \%)$ & 36 \\
Mild repression & $15(88 \%)$ & $2(12 \%)$ & 17 \\
Moderate repression & $52(80 \%)$ & $13(20 \%)$ & 65 \\
Extreme repression & $86(73 \%)$ & $32(27 \%)$ & 118 \\
Total & 186 & 50 & 236 \\
\hline
\end{tabular}

Note: Percentages refer to the percentages that are mediated or not within category. Pearson's $\chi^{2}=7.01, d f=3, p$-value $=0.07$. 
partial" mediators and related terms. ${ }^{40}$ In light of this, it is useful to examine the variation between external and internal mediators.

In Figure 5, we present disaggregated mediation data distinguishing between "domestic" mediators, originating from within the country where an uprising is taking place, and "international" mediators, entering the situation from outside. ${ }^{41}$ An example of an internal mediator is the Chilean Archbishop Juan Francisco Fresno who mediated between the authoritarian regime of Augusto Pinochet and the nonviolent opposition Allianza Democrática, which had launched a nonviolent movement of resistance utilizing street protests and general strikes. ${ }^{42}$ The GCC mediation efforts in Yemen, by contrast, are an example of an international mediator.

Once this distinction is made, we notice that the relatively stable mediation rate discussed above masks an underlying trend: an increasing proportion of mediation interventions in nonviolent conflicts is undertaken by international mediators that come in from the outside, including other governments, international organizations, and international nongovernmental organizations. The shift to international mediation started around the end of the Cold War and is surprisingly marked: whereas 18 of 26 (or 69 percent) domestic mediation events occured before the end of 1992, the midpoint in our data set, only 8 (or 31 percent) occured after this date. With regard to international mediation, the proportions are the reverse: Only nine of thirty-two (or 28 percent) international mediation attempts took place before the end of 1992, whereas twenty-three (or 72 percent) have happened since then.

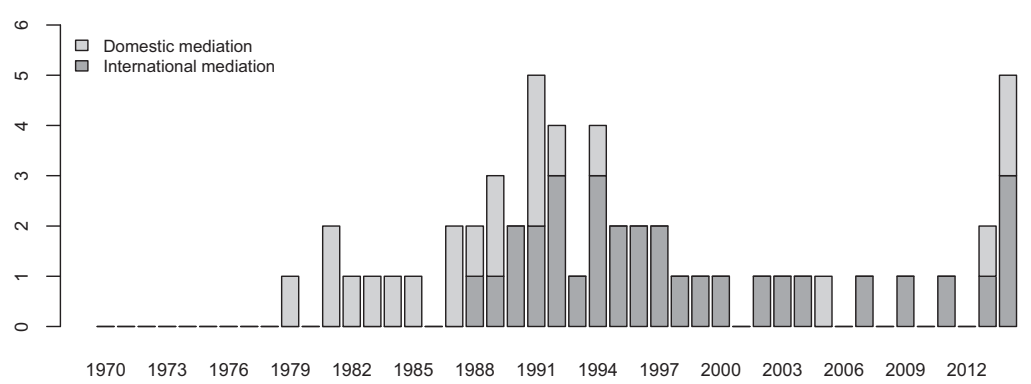

Figure 5. Mediated nonviolent campaigns, 1970-2014 by origins of mediator. 
The shift from domestic to international mediators is unlikely to depend upon any one factor, but three factors stand out as possible causes. First, the notion of state sovereignty has been gradually reinterpreted - normatively and legally-in the last twenty-five years, paving the way for more interventionist international actors, motivated by humanitarian and political concerns that were previously considered beyond reach. Second, perhaps owing to the previous development, international mediators have gradually accumulated greater expertise and professional resources, allowing them to respond to a greater number of mediation opportunities as they present themselves, potentially, of course, crowding out local mediators. Organizations such as the UN, in particular, have increased their mediation resources markedly since the end of the Cold War, and many other organizations have followed suit. ${ }^{43}$ Third, as globalization has intensified, the media attention awarded to uprisings in foreign countries has likely increased, drawing attention to the types of risks - of escalation and humanitarian costs - that may shift the mediator's calculation in favor of intervention, all else being equal.

Two cases could be highlighted as an illustration of this shift: Poland's Solidarity movement in the early years of 1980 s and Ukraine's "Euromaidan" protests of 2013-2014. With its extreme size (around ten million members) and charismatic leadership, Solidarity attracted significant international attention for its challenge to the Polish communist regime. Despite this international attention, all attempts at mediating between Solidarity and the Polish regime emerged domestically. ${ }^{44}$ Our data record not a single significant mediation attempt by international actors during the key years of the Solidarity movement. When protests erupted three decades later in Ukraine, another ex-communist country in Eastern Europe, the situation was the opposite: all mediation events recorded in our data are by international actors (European Union and Russia), and there are no recorded attempts by domestic actors.

\section{DISCUSSION}

This study has set out to examine the empirical trajectory of mediation occurring in nonviolent uprisings in the late twentieth and early twenty-first centuries. We have suggested, building on previous mediation literature, that the costs and risks of nonviolent conflicts should be positively associated with the occurrence of mediation. We 
find some initial support for this argument. Yet the aspiration has not been to suggest a comprehensive explanatory model for mediation, but to exploratively gauge the empirical domain. It is hoped that this can stimulate further research within this underresearched field. We draw this analysis to an end with a discussion of our empirical findings and their implications for policy and future research.

This study has shown that there is a nontrivial percentage of mediation engagements in nonviolent uprisings. As these uprisings stand the risk of escalating into civil wars, these mediation engagements can be thought of as attempts at conflict prevention. Earlier research on conflict prevention has pointed to the importance of managing conflicts before they turn violent or, if that is not possible, to stem further escalation after violence has begun. ${ }^{45}$ By showing that conflict parties are open to mediation in uprisings with potential to escalate to civil war, this study can help to reinvigorate both research and practice in conflict prevention. By engaging at an early stage of conflict, such as during a nonviolent uprising, policymakers and conflict resolution practitioners can help to transform conflicts, increasing the probability that they will follow constructive trajectories. In particular, there is a need to develop more timely and effective methods of bridging the gap between opposition movements and established regimes to open channels of communication and identify possible solutions that meet underlying interests of larger sections of societies, including those sections supporting a challenged regime, before cycles of violence and retaliation take hold. In this regard, it is important to empower insider peacemakers, who can potentially play an important role in bridging divides within conflict societies. Any type of engagement, however, needs to be based on an analysis that empowers those who seek democratic change, minimizing the risks that regimes seeking to defend the status quo could manipulate mediation efforts to buy time, delay democratic reforms, or divert attention from the need of fundamental social changes.

From a policy perspective, it is also important to develop institutional capacities to detect early signs of conflicts. Nonviolent uprisings represent one type of such early-warning signs. Beyond the practice of mediation, which we have studied here, there are other forms of diplomatic interventions that can be pursued in order to ensure that nonviolent uprisings do not turn destructive, including the use of factfinding missions, the supply of third-party monitors, and political pressure on regimes to restrain the use of repression. Direct outside 
support to opposition movements needs to be used cautiously as a general tool and should always be tailored to the specific contexts, as there are risks that such support may actually undermine the credibility of the democratic opposition and play into a commonly used discrediting narrative by threatened regimes casting their opposition as "foreign agents" and "traitors." An institutional development of thirdparty capacities would entail identifying approaches that seem to work, creating mechanisms for institutional learning, as well as sharing examples of best practices.

Our study may also contribute to research on nonviolent uprisings more generally. The focus in nonviolent research has been on identifying conditions for success defined in terms of an opposition achieving its aspirations. Yet relatively little attention has been paid toward examining negotiated settlements (as opposed to the field of conflict resolution, where this is rather the focal point of research). Additionally, research on the role of external actors in nonviolent uprisings has not primarily been on third-party mediators, but instead on how nonviolent uprisings or protests may be supported in the most constructive manner, or on the conditions under which support for regimes is withdrawn. ${ }^{46}$

One of the key differences between armed and unarmed opposition, beyond the use of violence, lies in their modes of organizational structure. Rebel groups tend to have hierarchical command and leadership structures, whereas nonviolent opposition groups usually are more broad-based and network organized. This observation in itself calls for more research on how mediation and group change interactions. Mediation can increase the risk of group heterogeneity. ${ }^{47}$ Mediation increases the risk of opposition group fragmentation change in group heterogeneity. ${ }^{48}$ Mediation is also more difficult in situations where there are wider group heterogeneity and more actors who can veto against potential agreements. ${ }^{49}$

Drawing this article to an end, it is important to point out an overall conclusion from this line of study: mediation and conflict resolution processes are indeed an important, although understudied, aspect of nonviolent uprisings. Although this study has not examined mediation effectiveness, it nevertheless shows the applicability of mediation in situations of large-scale social conflict. Mediation presents a range of possibilities for reducing the risk that nonviolent uprisings will escalate to civil war, improving the conditions for democratization, building stronger civil societies, and laying the groundwork for longterm peace. 


\section{NOTES}

We acknowledge generous support from the Marianne och Marcus Wallenberg Stiftelse, for the research project "Battles without bullets" MMW 2013.0025.

1. Jacob Bercovitch and Scott Sigmund Gartner, "Is There Method in the Madness of Mediation: Some Lessons for Mediators from Quantitative Studies of Mediation," International Interactions 32 (2006): 329-354; Derrick V. Frazier and William J. Dixon, "Third-Party Intermediaries and Negotiated Settlements, 19462000," International Interactions 32 (2006): 385-408; Kyle Beardsley, David M. Quinn, Bidisha Biswas, and Jonathan Wilkenfeld, "Mediation Style and Crisis Outcomes," Journal of Conflict Resolution 50, no. 1 (2006): 58-86.

2. Karl DeRouen, Jacob Bercovitch, and Paulina Pospieszna, "Introducing the Civil Wars Mediation (CWM) Dataset," Journal of Peace Research 48, no. 5 (2011): 663-672; Michael J. Greig and Patrick M. Regan, "When Do They Say Yes? An Analysis of the Willingness to Offer and Accept Mediation in Civil Wars," International Studies Quarterly 52, no. 52 (2008): 759-781; Patrick M. Regan and Aysegul Aydin, "Diplomacy and Other Forms of Intervention in Civil Wars," Journal of Conflict Resolution 50, no. 5 (2006): 736-756.

3. Gene Sharp, The Politics of Nonviolent Action (Boston: Porter Sargent Publisher, 1973).

4. Magnus Oberg, Frida Moller, and Peter Wallensteen, "Early Conflict Prevention in Ethnic Crises, 1990-98: A New Dataset," Conflict Management and Peace Science 26, no. 1 (2009): 67-91.

5. Kyle Beardsley, David E. Cunningham, and Peter B. White, "Resolving Civil Wars before They Start: The UN Security Council and Conflict Prevention in Self-Determination Disputes," British Journal of Political Science 47, no. 3 (2014): $1-23$.

6. An exception is Isak Svensson and Mathilda Lindgren, "Peace from the Inside: Exploring the Role of the Insider-Partial Mediator," International Interactions 39 (2013): 698-722, a study on which we build here. However, while Svensson and Lindgren discuss mediation selection, their focus is on mediation effectiveness.

7. Sharp, The Politics of Nonviolent Action; Erica Chenoweth and Kathleen Gallagher Cunningham, "Understanding Nonviolent Resistance: An Introduction," Journal of Peace Research 50, no. 3 (2013): 271-276. Nonviolent resistance was a central factor in fifty out of sixty-seven democratic transitions between 1973 and 2005; Peter Ackerman and Adrian Karatnycky, How Freedom Is Won-From Civic Resistance to Durable Democracy (New York: Freedom House, 2005).

8. Erica Chenoweth and Maria J. Stephan, Why Civil Resistance Works: The Strategic Logic of Nonviolent Conflict, Columbia Studies in Terrorism and Irregular Warfare (New York: Columbia University Press, 2011).

9. Ibid.; Ackerman and Karatnycky, How Freedom Is Won

10. Jonathan Sutton, Charles Butcher, and Isak Svensson, "Explaining Political Jiu-Jitsu: Institution Building and the Outcomes of Regime Violence against Unarmed Protesters," Journal of Peace Research 51, no. 5 (2014): 559-573; David Hess and Brian Martin, "Repression, Backfire, and the Theory of Transformative Events," Mobilization: An International Quarterly 11, no. 2 (2006): 249-267. 
11. Sharon Erickson Nepstad, "Mutiny and Nonviolence in the Arab Spring: Exploring Military Defections and Loyalty in Egypt, Bahrain, and Syria," Journal of Peace Research 50, no. 3 (2013): 337-349.

12. Svensson and Lindgren, "Peace from the Inside."

13. Peter Wallensteen and Isak Svensson, "Talking Peace: International Mediation in Armed Conflicts," Journal of Peace Research 51, no. 2 (2014): 315-327; James A. Wall Jr., John B. Stark, and Rhetta L. Standifer, "Mediation: A Current Review and Theory Development," Journal of Conflict Resolution 45, no. 3 (2001): 370-391; I. W. Zartman and J. Z. Rubin, "The Study of Power and the Practice of Negotiation," in Power and Negotiation, eds. I. W. Zartman and J. Z. Rubin (Ann Arbor: University of Michigan Press, 2000).

14. Jacob Bercovitch, "The Structure and Diversity of Mediation in International Relations," Mediation in International Relations: Multiple Approaches to Conflict Management, eds. Jacob Bercovitch and J. Z. Rubin (New York: St. Martin's Press, 1992), 1-29.

15. Greig and Regan, "When Do They Say Yes?"; Molly M. Melin, Scott Sigmund Gartner, and Jacob Bercovitch, "Fear of Rejection: The Puzzle of Unaccepted Mediation Offers in International Conflict," Conflict Management and Peace Science 30, no. 4 (2013): 354-368.

16. Oliver Richmond, "Devious Objectives and the Disputants' View of International Mediation: A Theoretical Framework," Journal of Peace Research 35, no. 6 (1998): 707-722; Kyle Beardsley, "Intervention without Leverage: Explaining the Prevalence of Weak Mediators," International Interactions: Empirical and Theoretical Research in International Relations 35, no. 3 (2009): 272-297.

17. Fred Charles Iklé, How Nations Negotiate (New York: Harper \& Row, 1964).

18. Jacob Bercovitch and Paul F. Diehl, "Conflict Management of Enduring Rivalries: The Frequency, Timing, and Short-Term Impact of Mediation," International Interactions 22, no. 4 (1997): 299-320.

19. Michael J. Greig, "Stepping into the Fray: When Do Mediators Mediate?" American Journal of Political Science 49, no. 2 (2005): 249-266.

20. Jacob Bercovitch and Richard Jackson, International Conflict: A Chronological Encyclopedia of Conflicts and Their Management 1945-1995 (Christchurch, New Zealand: Congressional Quarterly Inc., 1997).

21. C. R. Mitchell, "External Peace-Making Initiatives and Intra-National Conflict," Internationalization of Communal Strife, ed. Manus I. Midlarsky (London: Routledge, 1993), 274-296.

22. Anders Boserup and Andrew Mack, War without Weapons (London: Frances Pinter Publishers, 1975).

23. Véronique Dudouet, Nonviolent Resistance and Conflict Transformation in Power Asymmetries (Berlin: Berghof Research Center, 2008).

24. Adam Curle, Making Peace (London: Tavistock Publications, 1971).

25. Diana Francis, From Pacification to Peacebuilding: A Call to Global Transformation (London: Pluto Press, 2010).

26. Thomas Princen, Intermediaries in International Conflict (Princeton, New Jersey: Princeton University Press, 1992). 
27. Saadia Touval and I. W. Zartman, "Mediation in International Conflicts," in Mediation Research: The Process and Effectivenss of Third-Party Intervention, eds. Kenneth Kressel and Dean G. Pruitt (London: Jossey-Bass Publishers, 1989).

28. Erica Chenoweth and Orion A. Lewis, "Unpacking Nonviolent Campaigns: Introducing the Navco 2.0 Dataset," Journal of Peace Research 50, no. 3 (2013): 415-423.

29. Svensson and Lindgren, "Peace from the Inside."

30. Katariina Mustasilta and Isak Svensson, "Divided We Fall: Ethnic Cleavages and the Risk of Escalation in Nonviolent Uprisings, 1970-2014" (manuscript, 2018).

31. See NAVCO v1.1 codebook for details on definitions and for brief narratives on each campaign. Available at https:/www.du.edu/korbel/sie/media/docume nts/data/navco_1-1_appendix-and-codebook.pdf, accessed December 18, 2017.

32. Erica Chenoweth and Orion A. Lewis, "Unpacking Nonviolent Campaigns."

33. Availabel at https://nvdatabase.swarthmore.edu/. The Factiva search has utilized the terms "talks," "mediat*," "negotiat*," "dialogue," "fact-finding," "peace agreement," and "proposal," for each nonviolent uprising. The articles generated have been read manually and the occurrence of mediation has been coded. Complementing secondary sources have also been consulted and include encyclopedias, articles, and books on nonviolent action, many of which are also used for the compilation of the original NAVCO data set, including Roger S. Powers and William B. Vogele, Protest, Power, and Change : An Encyclopedia of Nonviolent Action from Act-up to Women's Suffrage (New York: Garland, 1997); April Carter, Howard Clark, and Michael Randle, People Power and Protest since 1945: A Bibliography of Nonviolent Action (London: Housmans Bookshop, 2006).

34. The two cases of mediated nonviolent campaigns in the Middle East took place in the context of the "Arab Spring" uprisings and their immediate aftermath. The first was the 2011 uprising in Yemen, targeting President Saleh, and the second was the 2013 anti-Morsi protests in Egypt.

35. Erica Chenoweth and Kurt Schock, "Do Contemporaneous Armed Challenges Affect the Outcomes of Mass Nonviolent Campaigns?" Mobilization: An International Quarterly 20, no. 4 (2015): 427-451.

36. Elizabeth Tompkins, "A Quantitative Reevaluation of Radical Flank Effects within Nonviolent Campaigns," Research in Social Movements, Conflicts and Change (Bingley, U.K.: Emerald Group Publishing, 2015), 103-135; Chenoweth and Schock, "Do Contemporaneous Armed Challenges Affect the Outcomes of Mass Nonviolent Campaigns?” 427-451.

37. We have also examined three other indicators of conflict characteristicsintensity, armed conflicts, and conflict duration-but none of these are significantly correlated with the occurrence of mediation, and we therefore do not discuss them here.

38. Francesco Mancini and Jose Vericat, Lost in Transition: Un Mediation in Libya, Syria, and Yemen (New York: International Peace Institute, 2016).

39. Magnus Lundgren, "Mediation in Syria: Initiatives, Strategies, and Obstacles, 2011-2016," Contemporary Security Policy 37, no. 2 (2016): 273-288. 
40. Marie Olson and Frederic S. Pearson, "Civil War Characteristics, Mediators, and Resolution," Conflict Resolution Quarterly 19, no. 4 (2002): 421-445; Dogukan Cansin Karakus and Isak Svensson, "Between the Bombs: Exploring Partial Ceasefires in the Syrian Civil War, 2011-2017," Terrorism and Political Violence (2017) 1-20; Paul Wehr and John Paul Lederach, "Mediating Conflict in Central America," Journal of Peace Research 28, no. 1 (1991): 85-98; Svensson and Lindgren, "Peace from the Inside."

41. We conceptualize insider partial mediators somewhat more restrictively than Wehr and Lederach, "Mediating Conflict in Central America." Whereas they define inside partial mediators as mediators from within the cultural region and context, we define insiders as those from within the same country as the conflict parties.

42. Genaro Arriagada, The Politics of Power, Pinochet (London: Unwin Hayman Inc., 1988).

43. The institutionalization of mediation resources is reflected in, among other things, an expansion of mediation-related staff and budgets. For example, the budget of the UN Department of Political Affairs, the body handling most of the UN's mediation efforts, increased by approximately 600 percent from the early 1990s to 2014 . More generally, an index that summarizes the mediation resources available to a sample of 13 IGOs more than doubled from 1992 to 2010. For further details on the quantification of the expansion of mediation capabilities, see Magnus Lundgren, "Conflict Management Capabilities of Peace-Brokering International Organizations, 1945-2010: A New Dataset," Conflict Management and Peace Science 33, no. 2 (2016): 198-223; Magnus Lundgren, "Which International Organizations Can Settle Civil Wars?” Review of International Organizations 12, no. 4 (2015): 613-641.

44. The Soviet Union did exert considerable influence over Poland during this time, naturally, but our data contain no observations of Soviet interventions that can be understood as mediation.

45. Jacob Bercovitch and Richard Wells, "Mediation and Conflict Prevention," in Peventing Violent Conflicts: Past Records and Future Challenges, ed. Peter Wallensteen (Uppsala: Department of Peace and Conflict Research, Uppsala University, 1999); Karl DeRouen and Shaun Goldfinch, "Putting the Numbers to Work: Implications for Conflict Prevention," Journal of Peace Research 42, no. 1 (2005): 27-45; Michael S. Lund, "Conflict Prevention: Theory in Pursuit of Policy and Practice," The Sage Handbook of Conflict Resolution, eds. Jacob Bercovitch, Victor Kremenyuk, and Wiliam I. Zartman (Los Angeles: SAGE, 2008), 285-321.

46. Véronique Dudouet, "Sources, Functions, and Dilemmas of External Assistance to Civil Resistance Movements," in Civil Resistance: Comparative Perspectives on Nonviolent Struggle, ed. Kurt Schock (Minnesota: University of Minnesota Press, 2015), 168-199.

47. Marie Olson Lounsbery and Alethia H. Cook, "Rebellion, Mediation, and Group Change: An Empirical Investigation of Competing Hypotheses," Journal of Peace Research 48, no. 1 (2011): 73-84.

48. Ibid.

49. David E. Cunningham, "Veto Players and Civil War Duration," American Journal of Political Science 50, no. 4 (2006): 875-892. 